\title{
THE LOUISIANA ALGEBRA I ONLINE INITIATIVE AS A MODEL FOR TEACHER PROFESSIONAL DEVELOPMENT: EXAMINING TEACHER EXPERIENCES
}

\author{
Laura M. O’Dwyer \\ Boston College \\ Lynch School of Education
}

Rebecca Carey

Glenn Kleiman

Education Development Center, Inc. (EDC)

The work was originally produced with funds from both the North Central Regional Educational Laboratory (NCREL) funding from the Institute of Educational Sciences (IES), U.S. Department of Education and the Louisiana Department of Education.

\begin{abstract}
Over the past decade online learning initiatives have shown tremendous potential for broadening educational opportunities and for addressing local and regional shortages of highly qualified K-12 teachers. The Louisiana Algebra I Online initiative represents one type of online model than can address both the need for improving course offerings and for addressing teacher shortages. The goal of the model is to improve educational opportunities for students by providing them with a high-quality, standardsbased curriculum delivered online by a certified mathematics teacher and to support the professional development of teachers in hard-to-staff schools by partnering them with a highly qualified teachermentor who is available online. The innovation of this model for online learning is that it integrates classroom-based learning with virtual learning thereby providing students with the structure and opportunities afforded by regular class meetings and supports the professional development of uncertified teachers through ongoing and embedded professional development opportunities.
\end{abstract}

This research suggests that the Louisiana Algebra I Online model is a viable online model for providing teachers with an effective model for authentic and embedded professional development that is relevant to their classroom experiences.

\section{KEYWORDS}

Online Learning, Algebra I, Virtual Learning, Distance Learning

\section{INTRODUCTION}

Online learning initiatives have shown tremendous potential for changing how teachers teach and how students learn and over the past decade, we have seen an enormous increase in the use of online teaching and learning environments at the $\mathrm{K}-12$ level. Researchers estimate that student enrollment in $\mathrm{K}-12$ online 
learning programs increased tenfold between 2002 and 2006; more than 600,000 students were enrolled in K-12 online learning programs during the 2005-2006 school year compared to only 40,000-50,000 students during the 2001-2002 school year [1]. In many cases, these online distance learning initiatives have been implemented to address critical local needs for (1) broadening the educational opportunities that are available for students by providing courses online that are not available locally and (2) addressing severe local and regional shortages of qualified teachers [2]. These advantages are particularly salient given the current mandates of The No Child Left Behind Act (NCLB) for improving student achievement and for providing students with highly qualified teachers in every classroom. According to NCLB, all teachers in core academic subjects are required to be highly qualified, including having an academic background in the subjects they teach, by the end of the 2005-06 school year [3].

Ever-increasing demands to improve student performance and teacher quality have led states to explore the potential of online learning programs. Within the umbrella term of "online learning program" there are myriad models through which coursework can be delivered. For example, during the 2002-2003 school year, many districts reported using two-way videoconferencing to teach classes $(55 \%)$ while others described asynchronous computer-based instruction delivered via the Internet (47\%) [4]. Other online models include pre-recorded video instruction, synchronous computer-based courses delivered via the Internet, or using other technologies such as teleconferencing or CD-ROM to provide instruction to students.

According to [4], hard-to-staff schools such as those in rural areas are leading the way in online course enrollment. This interest is fueled by the unique challenges faced by these districts and schools in recruiting and retaining highly qualified teachers that can provide a broad range of courses for students. For example, the National Educational Association reported that teachers in rural populations tend "to be less educated, slightly less experienced, younger," have limited access to professional development opportunities, and have a higher likelihood of teaching outside of their field [5]. According to [4], 46\% of rural districts reported that their students were participating in distance education courses compared with only $28 \%$ in urban school districts and $23 \%$ in suburban districts.

With its large number of rural school districts in which teacher recruitment and retention remain problems, Louisiana faces a particular challenge in helping students gain proficiency in core subject areas, and in mathematics in particular. According to [6], approximately $26 \%$ of public school students in Louisiana were enrolled in rural school districts during 2003-2004. Of this percentage, about 32\% were classified as minority students and $22 \%$ lived in poverty. Overall, $91 \%$ of Louisiana's teachers were classified as "highly qualified" during the 2003-2004 school year. However, when the data were disaggregated by school poverty level, it was evident that high poverty schools in Louisiana had lower percentages of highly qualified teachers. For example, during that school year, only $87 \%$ of teachers were considered highly qualified in the high poverty schools, compared to $93 \%$ of teachers in low poverty schools (2003-2004 Louisiana State Education Progress Report, http://www.doe.state.la.us).

In 2000, to broaden the course offerings taught by highly qualified teachers, Louisiana joined the ranks of several states offering online courses to students by launching Louisiana Virtual School (LVS). LVS uses the Internet, e-mail, technology tools, and other online and offline resources to enable Louisiana schools to provide students with access to a variety of courses that might not otherwise have been available. Starting with only 130 students during its pilot year in 2000, LVS grew to serve more than 2,300 students during the 2004-05 school year.

One particular program supported by the Louisiana Department of Education (LDE) and the State Board 
of Elementary and Secondary Education (SBESE), and offered through LVS is the Louisiana Algebra I Online initiative. This algebra course is delivered online via the Blackboard ${ }^{\mathrm{TM}}$ online learning platform and incorporates email, Internet tools such as Java Applets, and video into the lessons. Students also use graphing calculators and Graphire 2 Digital Tablets with a stylus and handwriting capture system. For students, the Louisiana Algebra I Online model integrates classroom-based learning with virtual learning, while also seeking to support the professional development of teachers in rural schools. In this way, the model not only provides instruction from a highly qualified teacher for students, but also provides local teachers with embedded professional development that is relevant to their classroom experiences.

Given the NCLB mandate for improving student achievement in core academic areas through the provision of highly qualified teachers in every classroom, it is not surprising that LVS would choose to focus some of their online learning resources on algebra instruction. The overarching skills acquired in the mastery of algebra include problem solving, being able to generalize from patterns, and applying mathematical reasoning to real-world problems [7] and its study is a vital step in students' education. A solid proficiency in Algebra is critical to success not only in more advanced mathematics [8], but also in students' education overall. Success or failure in this course has been found to be a major determinant of students' further work in mathematics and science and hence an important predictor of future educational attainment and employment opportunities [9].

\section{THE LOUISIANA ALGEBRA I ONLINE PROJECT}

Designed for schools in which a sufficient number of certified mathematics teachers are not available, the goal of the Louisiana Algebra I Online project is to improve educational opportunities for students by providing them with a high-quality, standards-based curriculum delivered online by a certified mathematics teacher. Additionally, this highly qualified teacher mentors a classroom teacher who is not certified to teach mathematics thereby providing an authentic and embedded professional development for local teachers that is relevant to their classroom experiences. The innovation of the Louisiana model is that it enables a school to have a certified teacher available when one is not locally present, while still providing students with the structure and opportunities afforded by regular class meetings.

\section{A. Teacher Roles and Responsibilities}

The online and in-class teachers are expected to play different instructional and management roles in the classroom. The online teacher serves as the teacher-of-record for students in the Algebra I Online classrooms and as a mentor and model for the in-class teacher. They are expected to respond to the students' questions and assignments, to provide feedback on homework, tests, and discussion board postings, to keep the students and the in-class teacher informed about student progress and status, maintain the schedule in the Blackboard ${ }^{\mathrm{TM}}$ course delivery system used for the online course, provide whole group and individual communications and instruction, and communicate with the in-class teacher. The online teachers report grades to LVS on a regular basis and maintain email backups to submit to LVS three times a year.

The in-class teachers, most of whom are either certified in other areas or are working towards certification in secondary mathematics, follow the curriculum guide to facilitate face-to-face learning activities and collaborate with the online teachers in guiding and supporting the students. The in-class teachers serve as collaborators with the online teacher and their responsibilities include creating an atmosphere conducive to learning in the classroom, assisting students with technology, supervising and instructing the Algebra I students, working with students when problems arise, communicating with the online teacher, keeping the online teacher informed about individual student issues and class activities, monitoring student grades, 
and providing feedback on activity days.

\section{B. Formal Components of Teachers' Professional Development Opportunities}

In addition to providing students with access to two teachers, this approach provides a unique professional development model for the in-class teachers since they work throughout the year with a highly qualified mathematics teacher who is available online. Both the in-class and online teachers participate in formal professional development workshops to prepare them for their participation in the Algebra I Online initiative. The formal professional development opportunities include the following activities:

\section{Summer Orientation}

This required, two-day session for the in-class and online teachers introduces them to each other and the course environment. It also provides an opportunity for the in-class and online teacher teams to begin planning the management of their collaboration throughout the year. The topics addressed included outlining the course organization and expectations, grading, review of teacher roles, classroom set-up and management, and technology tools. The in-class and online teacher also work together to create a schedule for at least the first semester of their collaboration, a plan for the daily routine for their classroom, a process on how grades will be reported, and a plan for how they will communicate with one another.

\section{Orientation to Algebra I Online for In-class Teachers}

This online, 11 module, four-week course is required for the in-class teachers and teachers are expected to spend two hours per week on the course. By the end of the course, the in-class teachers are expected to be able to (1) use Blackboard ${ }^{\mathrm{TM}}$ and email to communicate efficiently and effectively; (2) manage files in a Windows environment; (3) use the TI-83 graphing calculator and selected sensors; (4) use a digital tablet to capture handwritten work digitally; (5) identify and address major management issues in the secondary mathematics classroom; and (6) plan for daily activities in the algebra classroom.

\section{Orientation to Algebra I Online for Online Teachers}

This online, 17 module, four-week course is required for the online teachers and teachers are expected to spend two hours per week on the course. By the end of the course, the online teachers are expected to be able to (1) use Blackboard and email to communicate efficiently and effectively; (2) use Blackboard ${ }^{\mathrm{TM}}$ to manage an online classroom: make materials available, upload files, create announcements, create and manage discussion boards, use Blackboard's assessment feature, use the grade book tool; (3) manage files in a Windows environment; (4) use the TI-83 graphing calculator and selected sensors; (5) use specialized software to capture calculator screenshots and download calculator programs; (6) use a digital tablet to capture handwritten work digitally; (7) identify and address major management issues in the online mathematics classroom, including backups and documentation of work and communication; (8) help the in-class teacher plan for daily activities in the algebra classroom; and (9) develop a class schedule for each semester.

\section{Topics for Algebra Leaders and Instructors (TALI)}

This course is available to both in-class and online teachers through a regional state university. The course includes 11 online modules that parallel the Algebra I Online course and provides an overview of the administrative, instructional, technological, and pedagogical issues of the online Algebra I classroom. 
These modules are presented online over a ten-month period and coincide with the modules the students are completing in the classroom. Participants are required to spend a minimum of two hours per week on course activities.

\section{Curriculum and Textbooks}

The Algebra I Online course uses a curriculum designed by the Louisiana Center for Educational Technology (LCET) and the Louisiana School for Math, Science, and the Arts (LSMSA). The course is aligned to the National Council of Teachers of Mathematics (NCTM) standards and the Louisiana state content standards, benchmarks, and Grade Level Expectations (GLEs) (http://lvs.doe.state.la.us). Students enrolled in the Louisiana Algebra I Online program participate in an algebra class that meets on a standard class schedule, with all students meeting together in a technology-equipped classroom. Each student has access to a multimedia, Internet-connected computer during class time where the course curriculum and materials may be accessed. Students with access to an Internet-connected computer at home or elsewhere can also access their course materials outside of the school day. Each student benefits by having two teachers: an experienced secondary certified mathematics teacher who is available online and a teacher available in the classroom who is not necessarily certified to teach secondary mathematics.

During the first year of the course delivery (2002-2003), the Southwest Educational Development Laboratory (SEDL) included the Algebra I Online course as part of a study to determine the quality and effectiveness of curriculum, instruction, and student assessment in online courses. The study found that the Algebra I Online program met the criteria for an effective and quality web-based course for middle and high school students based on (1) alignment with state standards, (2) providing resources that enrich course content, (3) providing opportunities for students to engage in abstract thinking and critical reasoning skills, (4) providing appropriate student-to-student, as well as teacher-to-student interactions $[10]$.

\section{PRIOR RESEARCH AND CURRENT INQUIRY}

Despite the recent proliferation of online learning initiatives in $\mathrm{K}-12$ education, very little high-quality, evidence-based research is currently available to inform the choice and implementation of online programs. For example, there has been very little research on the effectiveness of online learning in K-12 compared to traditional face-to-face learning, and almost no research on specific curriculum interventions. In a meta-analysis of 19 research studies that examined $\mathrm{K}-12$ online programs, [11] found there to be preliminary evidence that students in online courses do as well as students who receive face-to-face instruction. However, only $10 \%$ of the studies examined by [11] employed an experimental or quasiexperimental approach. Similarly, another meta-analysis conducted by [12] found that only 2 of the 232 studies that focused on online learning at the $\mathrm{K}-12$ level employed experimental or quasi-experimental methods, used appropriate data analyses, or made conclusions appropriate to the methodology used. A more recent meta-analysis conducted by [13] reported that "[M] any studies of $\mathrm{K}-12$ distance education have been published, but a small proportion of them are controlled, systematic, empirical comparisons that fit the definition of 'scientific,' as it is defined by the U.S Department of Education and described at the What Works Clearinghouse website."

Much of the research-to-date on online teaching and learning has been conducted in higher education settings. These studies have found that online learning programs provide students and teachers with quite different teaching and learning environments than those provided in traditional, face-to-face settings [14, 15, 16]. The distinguishing characteristics include class structure [17], the level and types of peer-to-peer and student-teacher interactions that take place $[15,18]$, and the lack of "social presence" during the 
learning process $[19,20,21]$. While many studies of learning outcomes in higher education have found no statistical differences in achievement for online courses compared to traditional, face-to-face courses, there remains concern that the quality and depth of learning may be affected in online courses [22, 23, 24 25]. Mediating variables that may promote or hinder learning success in an online environment have been isolated in several studies and these include attitudes towards the online environment [26] and beliefs about the efficacy of online learning $[25,27,28,29,30]$.

The 2004-2005 school year implementation of the Louisiana Algebra I Online project provided a unique opportunity to use a quasi-experimental design to explore potential differences between students' experiences in online and traditional classrooms. Under this design, students participating in the initiative (treatment classrooms) were compared with students in matched comparison classrooms that received the traditional face-to-face or "business as usual" approach to instruction (comparison classrooms). During the 2004-2005 school year, the Louisiana Algebra I Online project was implemented in 18 intact classrooms in six school districts and two private schools. In total, 257 students participated in the Algebra I Online course and their survey responses and algebra achievement scores were compared with 232 students from 15 matched, comparison classrooms [31].

Using a hierarchical linear regression modeling approach in which 463 treatment and comparison group students were nested within 33 classrooms, examination of student achievement from the Louisiana Algebra I Online initiative found that after controlling for initial pre-intervention measures of mathematics ability, students who participated in the initiative scored as well on the posttest as students in traditional face-to-face Algebra I courses [31]. This finding is similar to those reported in other studies and meta-analyses which compared learning outcomes for online and face-to-face courses [13, 25, 27]. Since many online learning initiatives are implemented to fulfill critical local needs, this finding was very important as it showed that the Algebra I Online program was as effective as the traditional, face-to-face algebra classroom in improving student pre-to-post program learning outcomes.

Using survey data collected from students in the treatment and comparison classrooms, students' learning experiences were also compared. The data showed that students in the Algebra I Online classrooms responded positively to the online learning environment. They reported that they enjoyed the new learning experience and in particular, using technology to learn algebra. Interestingly, students in the Algebra I Online classrooms reported spending more time interacting with their peers to talk about the content of the course and working together on course activities than students in the traditional, face-toface classrooms. The amount of time that students spent socializing, interacting to understand assignment directions, and working together on both in-class assignments and homework were approximately the same in the traditional and online environments [31].

Despite having similar post-intervention algebra scores, the survey data showed that students in the Algebra I Online classrooms reported lower levels of confidence in their algebra skills than students in the traditional, face-to-face algebra courses [31]. This finding supports those from studies described by Bernard et al. [15] in their meta-analysis on how online and traditional classroom experiences may vary. It may be that the model of delayed feedback and dispersed authority in the online course lead to a "lost" feeling where students were unable to gauge "how they are doing."

\section{A. Focus of the Current Inquiry}

While our prior work examined student learning outcomes and student experiences, the focus of the current inquiry is on teachers' experiences in the Algebra I Online program and how these relate to student learning outcomes. Again, the 2004-2005 implementation of the Algebra I Online program 
provided us with the opportunity to examine the effectiveness of the initiative as a professional development opportunity for local teachers and to examine teacher practices and behaviors. Note that teacher data were not available from the comparison classrooms as the data collected were specific to the characteristics of the Algebra I Online program.

While the Algebra I Online model integrates classroom-based and virtual learning for students, it also supports the professional development of teachers by partnering local classroom teachers (who may not be certified to teach algebra) with highly qualified teachers who act as mentors throughout the implementation of the program. By providing classroom teachers with an individual mentor, albeit an online mentor, this model of professional development avoids the one-shot, one size fits all professional development approach that may not provide teachers with the opportunity to master new strategies for meeting the day-to-day veracity of their classrooms [32,33]. The design of the Algebra I Online program dovetails with the current literature on professional development as it provides for the "joint construction of knowledge through conversation and other forms of collaborative analysis and interpretation" [34]. According to [33], online models for teacher professional development have the potential to provide teachers with the "needed support and time which may currently not be available given the conventional school professional development frameworks (e.g., set hours or a number of days)."

Given these current thoughts on effective teacher professional development and the important professional development components of the Algebra I Online model, it is important to examine the initiative as a professional development model. Specifically, this research examines the online and inclass teachers' experiences in the program through the examination of teacher survey responses and the association between teachers' beliefs and practices and student learning outcomes. The current lack of sound empirical evidence about the impacts of online learning in $\mathrm{K}-12$ settings is troublesome given the widespread and growing use of online models for teaching, learning and teacher professional development and the costs incurred from limited school budgets to support its use.

\section{STUDY DESIGN AND SAMPLE CHARACTERISTICS}

In this section we describe the district and teacher characteristics, the instrumentation used to collect data and the steps taken to assess the fidelity of the implementation of the program. To participate in the Louisiana Algebra I Online program, districts were required to demonstrate a need for certified mathematics teachers and a desire to provide professional development to teachers interested in obtaining certification in secondary mathematics. District leaders were asked to identify the schools in which the program was to be implemented and the teachers who would serve as in-class teachers for the Algebra I program. In addition, participating schools were required to provide the hardware, computer access, and an email account for each student. They also agreed to provide release time for the participating teachers to attend the required professional development sessions and to identify a district coordinator who would oversee the registration process for the students.

\section{A. Sample Characteristics}

A total of six school districts and two private schools participated the Algebra I Online program during the 2004-2005 school year. According to the NCES 2001-02 School District Locator, four of the participating districts qualified as Rural or Small Town districts and the remaining two were classified as Urban Fringe of Mid-Size City districts. All six districts had previously participated in the Algebra I Online program during the 2003-2004 school year, and two had participated in the pilot year in 2002-03.

A total of 26 teachers participated in the Louisiana Algebra I Online program as either online or in-class 
teachers; 10 teachers taught online and 16 teachers acted as in-class teachers. The online teachers were selected on the basis of their outstanding teaching credentials and were identified by the Louisiana Department of Education to be at the level of "mentor teachers." These were master teachers who were certified to teach secondary mathematics and were experienced with technology. According to the data collected as part of the study, this group of teachers had an average of 11 years teaching experience with an average of 9.4 years in their current position, they taught an average of 4.9 classes per semester with an average class size of 17 students.

In the selection of in-class teachers, first priority was given to those teachers who were actively working toward their certification in secondary mathematics. Thirteen of the 16 in-class teachers were certified to teach elementary education and the remainder held certifications in middle school mathematics, special education, or health and physical education. The average number of years teaching for the in-class teachers was 8.5, and they taught an average of 5 classes per semester with an average class size of 21 students.

The Algebra I Online course was available to students in Grades 8 and 9 and there were no academic prerequisites for enrolling in the course. The course was not intended for those students who had previously failed algebra, so regardless of grade, students were taking Algebra I for the first time. Since online learning makes certain demands upon students beyond those in face-to-face algebra courses, the districts and schools were asked to avoid selecting students for participation on the basis of prior mathematics achievement. They were asked instead to consider students' ability to work independently, communicate effectively, and their ability to manage their time effectively. District coordinators were given instructions on how to identify students who would benefit from learning mathematics in a non-traditional setting. In total, 257 eighth and ninth grade students participated in the Louisiana Algebra I Online project during the 2004-2005 school year implementation.

\section{B. Instrumentation}

Survey instruments were administered to the in-class and online teachers to gather data about their practices and experiences in the Algebra I Online program. Prior to the implementation of the program, students were administered an achievement test to assess their general mathematics ability and at the end of the course, an aligned post-test was administered. In addition to these data sources, observational data were collected in a random sample of 9 classrooms to assess the fidelity of the implementation across the classrooms. Each data source will be discussed in turn.

\section{Teacher Surveys}

A 19 item survey was administered to both the in-class and online teachers. The in-class teacher survey was designed to collect information on teacher activities during the implementation of the Algebra I Online program, to gauge the teachers' satisfaction with the professional development opportunities and their mentee experiences, and to get a sense of their overall satisfaction with the program.

Similarly, the online teachers' survey was used to collect data on teacher activities during the implementation of the Algebra I Online program and on teachers' satisfaction with the professional development opportunities. In addition, this survey was used to assess the online teachers' experience working with the in-class teacher, and their satisfaction with the program overall. The online and in-class surveys were comprised of several groups of overlapping items but since some teacher survey items were only administered to one of the groups, comparisons across in-class and online teachers were not possible for all survey items. 


\section{Student Achievement Measures}

Administered in September 2004, the pretest was comprised of 25 multiple-choice items that assessed students' general mathematics ability and mathematics comprehension. The Cronbach's alpha estimate of reliability for the pretest was 0.70 . The posttest, administered in June 2005, was also a 25 item multiple choice test but was aligned with the Algebra I Online course objectives and Louisiana's GLEs outlined by the Louisiana Department of Education. The Cronbach's alpha estimate of reliability for the posttest was 0.81. Evidence of the content validity of the assessments was established by having two mathematics educators with experience developing curriculum and assessments map the items on the test to the Louisiana GLE and Algebra standards [31]. Evidence of criterion validity was gathered by correlating scores on the assessments with students' standardized test scores. Despite being unable to separate the algebra strand from the complete standardized test scores, the correlations between the Grade 8 Louisiana Educational Assessment Program (LEAP) assessment scores and the Grade 9 Iowa Test of Educational Development (Iowa) assessment and the pre- and posttest scores were moderately strong and positive; 0.55 and 0.67 for the pre- and posttest scores, respectively with the LEAP assessment and 0.50 and 0.55 , respectively for the pre- and posttest measures with the Iowa assessment [31].

For the treatment group, pretest achievement data were gathered from 261 students and posttest data were collected from 231 students. Since students in the treatment group and comparison groups were taking Algebra I for the first time regardless of grade, data from both grades were combined for analysis.

\section{Fidelity of Program Implementation}

To assess the fidelity of the implementation of the Algebra I Online program, classroom observations were conducted in a sample of the treatment group classrooms; nine of the eighteen classrooms. The classroom observations documented the types of instructional phases (i.e., transition, whole group instruction/discussion, student individual work, etc.), the roles fulfilled by the in-class teacher, and types of student interactions across the treatment classrooms. Additional observational data recorded how the technologies were used and how the classrooms were set-up. Two trained researchers observed one class period in each of nine classrooms, working together and observing the same classes at the same time. During the class period observation, both researchers recorded the length and description of the instructional phases independently. Their observations of the instructional phases were entirely consistent with an inter-rater reliability of $100 \%$. Within each phase, observers took descriptive notes on the student to student interaction, teacher to student interaction, student engagement with the task, technology use, and a general description of the activity. Additionally, both observers recorded the instructional roles the in-class teacher fulfilled and the classroom organization (i.e., lecture, lecture with discussion, small group instruction, individual work, teacher demonstration, etc.). Again, their observations were entirely consistent within each classroom. Immediately after each class, the researchers came to a consensus on the post-class checklist that includes items about the observations of students' mathematical thinking, discipline incidents, uses of technology, and students' levels of comfort with technology. With two trained observers in each of the nine classrooms, the classroom observation data showed high levels of similarity among the activities being conducted across the treatment classrooms, and in each case these activities were directly linked with how the course content was presented. For example, in each of the treatment classrooms, students used technology to "analyze information," "evaluate information," and "self-assess or assess" their own work or work from classmates [35].

\section{RESULTS}

In total, 26 Algebra I Online teachers completed the teacher surveys; 16 in-class teachers and 10 online teachers. To examine the Louisiana Algebra I program as a professional development model, online and 
in-class teachers' survey responses are compared under several headings relating to their experience with the program. Where variability in teachers' responses permitted comparisons, students' posttest scores were compared across groups of teachers. For these comparisons, individual student posttest scores were used rather than classroom mean scores. Note that although some online teachers taught more than one online class, they only completed the one survey.

\section{A. Resources and Support}

Table 1 shows that in general, the online and in-class teachers were positive about the formal professional development opportunities that were available as part of the Algebra I Online model. More than $90 \%$ of the online and in-class teachers either agreed or strongly agreed that the two-day summer orientation and the ongoing professional development opportunities were beneficial and applicable to their teaching experiences. Similarly, in terms of technical resources and support in their classrooms, schools and districts, the in-class and online teachers were very positive. Recalling that local schools and districts had to provide the technology hardware and computer and email access for students, and agreed to provide release time for the participating teachers to attend the required professional development sessions, this finding is encouraging. Prior research on technology use has found that local support for educational technology is a significant positive predictor of teachers' integration technology into their teaching practices [36] and has been found to be positively related to teachers' satisfaction with their technology experiences. Since adequate access to educational technology is a necessary but insufficient condition for technology use and integration into classroom instruction and learning, these findings are encouraging. Without local support and adequate resources, the tenability of Louisiana Algebra I Online program would certainly be jeopardized.

Beyond their local schools and districts, the teachers were also very positive about the support they received from the Algebra I Online staff; each of the in-class and online teachers either strongly agreed or agreed that they received adequate support from the trained Algebra I Online staff. The lack of variability in teacher responses did not permit the examination of student learning outcomes.

Table 1: Resources and Support

\begin{tabular}{|c|c|c|c|}
\hline & & $\begin{array}{l}\text { Strongly Agree } \\
\text { or Agree }\end{array}$ & $\begin{array}{l}\text { Strongly Disagree } \\
\text { or Disagree }\end{array}$ \\
\hline \multirow{2}{*}{$\begin{array}{l}\text { The two-day summer orientation for the } \\
\text { Algebra I Online Project was beneficial and } \\
\text { applicable to my teaching experiences. }\end{array}$} & Online Teachers & $10(100 \%)$ & $0(0 \%)$ \\
\hline & In-class Teachers & 15 (94\%) & $1(6 \%)$ \\
\hline \multirow{2}{*}{$\begin{array}{l}\text { The ongoing professional development for the } \\
\text { Algebra I Online Project was beneficial and } \\
\text { applicable to my teaching experiences. }\end{array}$} & Online Teachers & $9(90 \%)$ & $1(10 \%)$ \\
\hline & In-class Teachers & $15(94 \%)$ & $1(6 \%)$ \\
\hline \multirow{2}{*}{$\begin{array}{l}\text { The technical resources in my classroom are } \\
\text { adequate. }\end{array}$} & Online Teachers & $10(100 \%)$ & $0(0 \%)$ \\
\hline & In-class Teachers & $15(94 \%)$ & $1(6 \%)$ \\
\hline \multirow{2}{*}{$\begin{array}{l}\text { The school and district provided adequate } \\
\text { support. }\end{array}$} & Online Teachers & $10(100 \%)$ & $0(0 \%)$ \\
\hline & In-class Teachers & $15(94 \%)$ & $1(6 \%)$ \\
\hline \multirow{2}{*}{$\begin{array}{l}\text { The Algebra I Project staff provided adequate } \\
\text { support. }\end{array}$} & Online Teachers & $10(100 \%)$ & $0(0 \%)$ \\
\hline & In-class Teachers & $16(100 \%)$ & $0(0 \%)$ \\
\hline
\end{tabular}




\section{B. Levels of Interest in the Online Environment}

Since teaching an online course is likely to present teachers with quite a different teaching environment than that in a traditional, face-to-face setting $[14,15,16]$, it is interesting to examine how teachers rate their level of interest in the online classroom environment. Table 2 shows that compared to their level of interest in a regular classroom environment, the majority of in-class and online teachers said that their interest was either somewhat or much higher. A greater percentage of the online teachers $(90 \%)$ reported higher levels of interest than the in-class teachers $(75 \%)$. This is not surprising since the online teacherleaders were more experienced with the online environment than their in-class mentees (recall that a prerequisite for being selected as an online teacher was that of being experienced with technology).

Prior research has found that students' success in an online learning environment has been found to be associated with more positive attitudes towards the online environment [26] and more positive beliefs about the efficacy of online learning [25, 27, 28, 29, 30]. Table 2 shows that when the in-class and online teachers were asked to rate their students' level of interest in the online course compared to a regular course, the in-class teachers reported lower levels of interest for their students; 4 of the 16 in-class teachers indicated that their students' level of interest was somewhat or much lower than for a traditional course. All 10 of the online teachers said that their students' level of interest was either the same, somewhat higher or much higher; in speculating about the difference between the two ratings, it may be that the online teachers were less familiar with the students' interest levels because they were not physically present in the classroom.

This finding raises some important issues about online learning environments in general and the Algebra I Online program in particular. For online teachers, their physical absence in the classroom may lead to the under or over-estimation of students' progress or motivation, while for students', the delayed feedback and the absence of their teacher-of-record in the online classroom may make it difficult for students to gauge their progress in the course. This hypothesis is somewhat supported by the finding reported in [31] that despite having similar post-intervention algebra scores, the students in the Algebra I Online classrooms reported lower levels of confidence in their algebra skills than students in the traditional, faceto-face algebra courses.

Table 2: Level of Interest in the Online Classroom Environment

\begin{tabular}{|c|c|c|c|c|}
\hline & & $\begin{array}{c}\text { Much or } \\
\text { Somewhat Higher }\end{array}$ & $\begin{array}{l}\text { About the } \\
\text { Same }\end{array}$ & $\begin{array}{c}\text { Much or } \\
\text { Somewhat Lower }\end{array}$ \\
\hline \multirow{2}{*}{$\begin{array}{l}\text { How would you describe your } \\
\text { own level of interest in the online } \\
\text { classroom environment in } \\
\text { comparison to a regular } \\
\text { classroom environment? }\end{array}$} & Online Teachers & $9(90 \%)$ & $1(10 \%)$ & $0(0 \%)$ \\
\hline & In-class Teachers & $12(75 \%)$ & $2(13 \%)$ & $2(13 \%)$ \\
\hline \multirow{2}{*}{$\begin{array}{l}\text { How would you describe the } \\
\text { students' level of interest in the } \\
\text { online course in comparison to a } \\
\text { regular course? }\end{array}$} & Online Teachers & $8(80 \%)$ & $2(20 \%)$ & $0(0 \%)$ \\
\hline & In-class Teachers & $9(56 \%)$ & $3(19 \%)$ & $4(25 \%)$ \\
\hline
\end{tabular}

To examine whether teachers' level of interest in the online classroom environment was associated with students' posttest scores, the mean student posttest scores were calculated for the groups of teachers who expressed different levels of interest in the online classroom environment. The significance of the difference between the means was then examined using either an independent means t-test or the one-way 
ANOVA. Note that for the independent means t-tests, an adjusted alpha-level is used to adjust for multiple comparisons within a single data set.

For the online teacher responses, an independent means t-test was used to examine whether students' posttest scores differed according to teachers' self-reported level of interest in the online classroom environment. The results in Table 3 show that there was no significant difference between posttest scores for teachers who reported having a much or somewhat higher level of interest (15.24) and the posttest scores for teachers who reported interest levels about the same as those for a regular classroom environment (16.41) $(\mathrm{t}=-1.08, \mathrm{df}=110, \mathrm{p}=0.284)$. To examine the same question for three groups of inclass teachers, a one-way ANOVA was used. Similar to the results for the online teachers, the ANOVA showed that there were no significant differences between students' posttest scores for teachers who said that their level of interest was much or somewhat higher (14.68), about the same (15.79), or much or somewhat lower $(16.23)(\mathrm{F}(2,210)=1.85, \mathrm{p}=.160)$. These results suggest that teachers' level of interest in the online environment was not associated with higher or lower posttest scores for students.

Looking at how students' posttest scores differed across teachers' perceptions of students' level of interest in the online environment, similar analyses were conducted. Table 3 shows that students whose online teacher perceived them to have a much or somewhat higher level of interest (16.55) scored significantly higher than students whose online teacher said that their level of interest was about the same $(10.81)(t=$ 5.97, $\mathrm{df}=110, \mathrm{p}<.001)$. Examining the in-class teachers' perceptions of student interest, the data show that students' whose teachers perceived them to have much or somewhat lower levels of interest scored lower on the posttest (11.86). The ANOVA conducted to examine the difference was significant $(\mathrm{F}(2$, $210)=19.20, \mathrm{p}<.001)$ and post hoc Bonferroni tests showed that these students scored significantly lower than students whose in-class teachers perceived their interested level to be about the same (p $<$ $.001)$ or whose in-class teachers perceived their interested level to be much or somewhat higher $(\mathrm{p}<.001)$ in comparison to a regular classroom environment. Recognizing that these are not direct measures of students' level of interest in the online environment, but rather teachers' perceptions of student interest, the results remain interesting.

Table 3: Student Posttest Means and Level of Interest in the Online Classroom Environment

\begin{tabular}{llccc}
\hline & & $\begin{array}{c}\text { Much or } \\
\text { Somewhat } \\
\text { Higher }\end{array}$ & $\begin{array}{c}\text { About the } \\
\text { Same }\end{array}$ & $\begin{array}{c}\text { Much or } \\
\text { Somewhat } \\
\text { Lower }\end{array}$ \\
\hline $\begin{array}{l}\text { How would you describe } \\
\text { your own level of interest in } \\
\text { the online classroom } \\
\begin{array}{l}\text { environment in comparison } \\
\text { to a regular classroom } \\
\text { environment? }\end{array}\end{array}$ & $\begin{array}{l}\text { Students' Posttest Mean for } \\
\text { Online Teachers (s.e.) }\end{array}$ & $15.24(.50)$ & $16.41(.71)$ & N/A \\
\cline { 2 - 5 } & $\begin{array}{l}\text { Students' Posttest Mean for } \\
\text { In-class Teachers (s.e.) }\end{array}$ & $14.68(1.07)$ & $15.79(.58)$ & $16.23(.38)$ \\
\hline $\begin{array}{l}\text { How would you describe the } \\
\text { students' level of interest in } \\
\text { the online course in } \\
\begin{array}{l}\text { comparison to a regular } \\
\text { course? }\end{array}\end{array}$ & $\begin{array}{l}\text { Students' Posttest Mean for } \\
\text { Online Teachers (s.e.) }\end{array}$ & $16.55(.41)$ & $10.81(.90)$ & N/A \\
\cline { 2 - 5 } & $\begin{array}{l}\text { Students' Posttest Mean for } \\
\text { In-class Teachers (s.e.) }\end{array}$ & $15.99(.39)$ & $16.31(.66)$ & $11.86(.56)$
\end{tabular}

Note: The alpha level was adjusted separately for online teacher comparisons. Significance was established using $\alpha / 2=$ .025 for the online teachers.

\section{Challenges in Teaching the Algebra I Online Course}

When the in-class and online teachers were asked to identify the biggest challenges they faced in 
facilitating and teaching the Algebra I Online course, the in-class teachers reported facing more challenges than the online teachers. Table 4 shows that these challenges included lack of teaching experience and lack of familiarity with technology, as well as having technical problems in the classroom. Also, half the in-class teachers reported that substantiating student participation was a challenge. A smaller number of the online teachers reported technical problems and having difficulties substantiating student participation as challenges. None of the teachers in either group reported that insufficient professional development opportunities or lack of support were obstacles to teaching the Algebra I Online course. These findings triangulate with the data reported in Table 1 where in-class and online teachers were generally positive about the available professional development opportunities and the support and resources they received.

To explore whether the challenges reported by the teachers were related to student achievement, the difference between the mean posttest scores for students in classrooms where teachers reported challenges and the mean posttest scores for students in classrooms where challenges were not reported were examined using independent means t-tests. Note that due to the lack of variability on some of the challenges reported, only the challenges of lack of teaching experience, lack of familiarity with technology, facing technical problems and substantiating student participation were examined in this way. Similar to the previous analyses, disaggregated student data were used for these analyses. Again, an adjusted alpha-level used to adjust for multiple comparisons within a single data set.

The mean posttest score for students whose in-class teachers reported their lack of teaching experience as a challenge (11.81) was statistically significantly lower than the mean for students whose in-class teachers did not report such a challenge $(15.73)(t=4.67, \mathrm{df}=221, \mathrm{p}<.001)$. Similarly, the mean posttest scores for students whose in-class teachers reported that their lack of familiarity with technology was a challenge (10.56) was statistically significantly lower than the mean for students whose teachers did not report a lack of familiarity with technology $(16.14)(\mathrm{t}=7.75, \mathrm{df}=221, \mathrm{p}<.001)$.

In looking at the difference between the mean posttest scores for students whose in-class teacher reported facing technical difficulties (14.51) and the mean for those whose teachers did not report such a challenge (15.59), the data show that while the students whose in-class teachers reported this as a challenge scored lower, the difference was not statistically significant $(\mathrm{t}=1.73, \mathrm{df}=221, \mathrm{p}=.086)$.

However, the mean posttest scores for students in the classrooms where the in-class teacher reported having difficulty substantiating student participation (13.47) was statistically significantly lower than the mean for classrooms in which the in-class teachers did not report these difficulties $(16.81)(t=5.82, d f=$ $205, \mathrm{p}<.001)$.

For the online teachers, students' posttest scores were slightly lower for those teachers who reported technical problems as a challenge (14.87) when compared to the online teachers who did not (15.70). However, the difference was not statistically significant $(\mathrm{t}=0.87 \mathrm{df}=110, \mathrm{p}=.389)$. In classrooms where the online teachers reported having difficulty substantiating student participation (16.76), students' posttest scores were statistically significantly higher than for students whose online teacher did not report this as a challenge $(14.23)(\mathrm{t}=-3.06, \mathrm{df}=110, \mathrm{p}<.01)$. This finding is somewhat unusual and would warrant future research. 
The Louisiana Algebra I Online Initiative as a Model for Teacher Professional Development: Examining Teacher Experiences

Table 4: Challenges in Teaching the Algebra I Online Course

\begin{tabular}{l|ll}
\hline & \multicolumn{1}{|c}{$\begin{array}{c}\text { Number of in-class teachers } \\
\text { identifying this as challenge } \\
\text { (total N = 16) }\end{array}$} & $\begin{array}{c}\text { Number of online teachers } \\
\text { identifying this as challenge } \\
\text { (Total N = 10) }\end{array}$ \\
\hline $\begin{array}{l}\text { Insufficient professional development } \\
\text { opportunities }\end{array}$ & $0(0 \%)$ & $0(0 \%)$ \\
Lack of support & $0(0 \%)$ & $0(0 \%)$ \\
Lack of materials/resources & $1(6 \%)$ & $0(0 \%)$ \\
Lack of teaching experience & $3(19 \%)$ & $0(0 \%)$ \\
Lack of familiarity with technology & $3(19 \%)$ & $1(10 \%)$ \\
Technical problems & $6(38 \%)$ & $3(30 \%)$ \\
Substantiating student participation & $8(50 \%)$ & $3(30 \%)$ \\
\hline
\end{tabular}

Note: The alpha level was adjusted separately for online and in-class teacher comparisons. Significance was established using $\alpha / 2=.025$ for the online teachers and $\alpha / 4=.013$ for the in-class teachers.

\section{Teaching in the Algebra I Online Program}

In addition to reporting on the challenges they faced in teaching the Algebra I Online classes, the in-class and online teachers were asked to respond to several questions about the benefits they perceived from their participation. These benefits related to increasing their comfort with technology, their knowledge of algebra content, increasing their understanding of students' learning and thinking, and increasing their classroom teaching skills. As Table 5 shows, the in-class and online teachers were very positive about the benefits of the Algebra I Online program. The one exception to this was that 5 of the 16 in-class teachers reported that they perceived no benefit from the program for increasing their classroom teaching skills.

Though it is encouraging to see that all 16 of the in-class teachers reported that the program increased their knowledge of algebra, the lack of perceived benefit for their classroom teaching skills is not entirely surprising. When serving as in-class teachers for the Algebra I Online program, teachers served as collaborators with the online teacher and their responsibilities included creating an atmosphere conducive to learning, assisting students with technology, supervising and instructing the Algebra I students, working with students when problems arise, keeping the online teacher informed about individual student issues and class activities, monitoring student grades, and providing feedback on activity days. In many ways, these roles are quite different from the typical role fulfilled by a classroom teacher in the traditional face-to-face environment. The data suggest that while the Algebra I Online model provides for improving content knowledge in algebra, the mentor-mentee relationship does not necessarily result in a model for changing general teaching practices.

Table 5: Benefits of Teaching in the Algebra I Online Program

\begin{tabular}{|c|c|c|c|}
\hline $\begin{array}{l}\text { My experience as an Algebra I Online } \\
\text { teacher contributed to... }\end{array}$ & & $\begin{array}{l}\text { Strongly Agree or } \\
\text { Agree }\end{array}$ & $\begin{array}{l}\text { Strongly Disagree or } \\
\text { Disagree }\end{array}$ \\
\hline \multirow{2}{*}{$\begin{array}{l}\text {...an increase in my comfort with using } \\
\text { technology }\end{array}$} & Online Teachers & $10(100 \%)$ & $0(0 \%)$ \\
\hline & In-class Teachers & $16(100 \%)$ & $0(0 \%)$ \\
\hline \multirow{2}{*}{....an increase in my knowledge of algebra } & Online Teachers & $10(100 \%)$ & $0(0 \%)$ \\
\hline & In-class Teachers & $16(100 \%)$ & $0(0 \%)$ \\
\hline \multirow{2}{*}{$\begin{array}{l}\text {...an increase in my understanding of } \\
\text { students' learning and thinking }\end{array}$} & Online Teachers & $10(100 \%)$ & $0(0 \%)$ \\
\hline & In-class Teachers & $15(94 \%)$ & $1(6 \%)$ \\
\hline \multirow{2}{*}{$\begin{array}{l}\text {...an increase in my classroom teaching } \\
\text { skills }\end{array}$} & Online Teachers & $10(100 \%)$ & $0(0 \%)$ \\
\hline & In-class Teachers & $11(69 \%)$ & $5(31 \%)$ \\
\hline
\end{tabular}


The Louisiana Algebra I Online Initiative as a Model for Teacher Professional Development: Examining Teacher Experiences

\section{E. Communication Between In-class and Online Teachers}

The online and in-class teachers fulfilled different and complementary roles during the teaching process and so the model required the in-class and online teachers to communicate about a variety of classroom issues. Recall that the online teachers served as the teacher-of-record for students in the Algebra I Online classrooms and were expected to respond to the students' questions and assignments, to provide feedback on homework, tests, and discussion board postings, to keep the students and the in-class teacher informed about student progress and status, to provide whole group and individual communications and instruction.

To develop an understanding of the implementation of the Algebra I Online program, it was necessary to examine the frequency with which the pairs of teachers communicated with each other for a variety of purposes. The in-class teachers were asked how frequently they communicated with the online teacher for each purpose, and the online teachers were asked how frequently they communicated with the in-class teachers for each purpose. As Table 6 shows, the teachers communicated most frequently (about once per week or daily/almost daily) for planning lessons and for discussing individual students' work. More than half the online and in-class teachers reported communicating with each other at least once per week, almost daily or daily for planning lessons and discussing individual student's work. The teachers communicated less frequently for planning and grading assignments, and for assisting with the use of technology.

Table 6: Communication Between In-class and Online Teachers

\begin{tabular}{|c|c|c|c|c|c|}
\hline \multicolumn{2}{|c|}{$\begin{array}{l}\text { How often do you communicate with the in- } \\
\text { class/online teacher for... }\end{array}$} & Never or rarely & $\begin{array}{l}\text { About once } \\
\text { per month }\end{array}$ & $\begin{array}{l}\text { About once } \\
\text { per week }\end{array}$ & $\begin{array}{l}\text { Daily/almost } \\
\text { daily }\end{array}$ \\
\hline \multirow{2}{*}{ Planning lessons } & Online Teachers & $0(0 \%)$ & $1(10 \%)$ & $8(80 \%)$ & $1(10 \%)$ \\
\hline & In-class Teachers & $3(19 \%)$ & $0(0 \%)$ & $8(50 \%)$ & $5(31 \%)$ \\
\hline \multirow{2}{*}{ Planning assignments } & Online Teachers & $0(0 \%)$ & $3(30 \%)$ & $7(70 \%)$ & $0(0 \%)$ \\
\hline & In-class Teachers & $3(19 \%)$ & $8(50 \%)$ & $4(25 \%)$ & $1(6 \%)$ \\
\hline \multirow{2}{*}{ Grading assignments } & Online Teachers & $1(10 \%)$ & $4(40 \%)$ & $4(40 \%)$ & $1(10 \%)$ \\
\hline & In-class Teachers & $10(63 \%)$ & $5(31 \%)$ & $1(6 \%)$ & $0(0 \%)$ \\
\hline \multirow{2}{*}{$\begin{array}{l}\text { Discussing individual } \\
\text { student's work }\end{array}$} & Online Teachers & $0(0 \%)$ & $4(40 \%)$ & $6(60 \%)$ & $0(0 \%)$ \\
\hline & In-class Teachers & $3(19 \%)$ & $3(19 \%)$ & $6(38 \%)$ & $4(25 \%)$ \\
\hline \multirow{2}{*}{$\begin{array}{l}\text { Assisting with the use of } \\
\text { technology }\end{array}$} & Online Teachers & $3(30 \%)$ & $4(40 \%)$ & $3(30 \%)$ & $0(0 \%)$ \\
\hline & In-class Teachers & $0(0 \%)$ & $10(63 \%)$ & $5(31 \%)$ & $1(6 \%)$ \\
\hline
\end{tabular}

To look at whether patterns of communication were associated with student achievement, we dichotomized the frequency of communication variable resulting in a measure that allowed us to compare student outcomes for teachers who seldom communicated (those who communicated "never or rarely" or "about once per month") to those who frequently communicated (those who communicated "about once per week" or "daily/almost daily"). Independent means t-tests were then used to compare posttest mean scores for the students of teachers in each group. Again, an adjusted alpha-level was used to adjust for multiple comparisons within a single data set.

The results in Table 7 show there are differences in students' posttest scores according to whether teachers seldom or frequently communicate, and the differences vary according to the purpose of the 
communication. For example, students' posttest mean scores were statistically significantly higher for online teachers who communicated frequently with the in-class teacher for planning lessons (16.04) and for discussing individual student's work (16.91) than online teachers who seldom communicated about these issues $(11.15,12.44$, respectively). Similarly, the mean posttest score for students whose in-class teachers communicated frequently with them online for planning assignments (16.63) was statistically significantly higher than that for in-class teachers who seldom communicated for assignment planning (14.41).

For in-class teachers who communicated frequently with the online teacher around technology issues (11.11), the student mean posttest scores were statistically significantly lower than for those teachers who seldom communicated for this purpose (15.25). There was no significant difference in student mean posttest scores according to how frequently in-class and online teachers reported communicating for grading assignments.

Table 7: Student Posttest Means and Communication Between In-class and Online Teachers

\begin{tabular}{|c|c|c|c|c|c|c|}
\hline \multicolumn{2}{|c|}{$\begin{array}{l}\text { How often do you communicate with the in- } \\
\text { class/online teacher for... }\end{array}$} & $\begin{array}{c}\text { Seldom } \\
\text { Communicate }\end{array}$ & $\begin{array}{l}\text { Frequently } \\
\text { Communicate }\end{array}$ & $\mathrm{t}$ & df & $p$-value \\
\hline \multirow{2}{*}{ Planning lessons } & $\begin{array}{l}\text { Students' Posttest } \\
\text { Mean for Online } \\
\text { Teachers (s.e.) }\end{array}$ & $11.15(1.04)$ & $16.04(.44)$ & -3.86 & 110 & $.000^{*}$ \\
\hline & $\begin{array}{l}\text { Students' Posttest } \\
\text { Mean for In-class } \\
\text { Teachers (s.e.) }\end{array}$ & $15.72(.73)$ & $14.89(.35)$ & 1.09 & 211 & .275 \\
\hline \multirow{2}{*}{ Planning assignments } & $\begin{array}{l}\text { Students' Posttest } \\
\text { Mean for Online } \\
\text { Teachers (s.e.) }\end{array}$ & $14.77(.54)$ & $17.09(.59)$ & -2.54 & 110 & .013 \\
\hline & $\begin{array}{l}\text { Students' Posttest } \\
\text { Mean for In-class } \\
\text { Teachers (s.e.) }\end{array}$ & $14.41(.39)$ & $16.63(.47)$ & -3.29 & 211 & $.000 *$ \\
\hline \multirow{2}{*}{ Grading assignments } & $\begin{array}{l}\text { Students' Posttest } \\
\text { Mean for Online } \\
\text { Teachers (s.e.) }\end{array}$ & $15.96(.57)$ & $14.76(.65)$ & 1.37 & 110 & .173 \\
\hline & $\begin{array}{l}\text { Students' Posttest } \\
\text { Mean for In-class } \\
\text { Teachers (s.e.) }\end{array}$ & $15.06(.32)$ & $15.50(1.31)$ & -0.39 & 211 & .819 \\
\hline \multirow{2}{*}{$\begin{array}{l}\text { Discussing individual } \\
\text { student's work }\end{array}$} & $\begin{array}{l}\text { Students' Posttest } \\
\text { Mean for Online } \\
\text { Teachers (s.e.) }\end{array}$ & $12.44(.73)$ & $16.91(.45)$ & -5.43 & 110 & $.000^{*}$ \\
\hline & $\begin{array}{l}\text { Students' Posttest } \\
\text { Mean for In-class } \\
\text { Teachers (s.e.) }\end{array}$ & $13.96(.43)$ & $16.28(.43)$ & 3.79 & 211 & $.000 *$ \\
\hline \multirow{2}{*}{$\begin{array}{l}\text { Assisting with the use of } \\
\text { technology }\end{array}$} & $\begin{array}{l}\text { Students' Posttest } \\
\text { Mean for Online } \\
\text { Teachers (s.e.) }\end{array}$ & $15.92(.61)$ & $14.83(.57)$ & 1.26 & 110 & .221 \\
\hline & $\begin{array}{l}\text { Students' Posttest } \\
\text { Mean for In-class } \\
\text { Teachers (s.e.) }\end{array}$ & $15.25(.32)$ & $11.11(.92)$ & -2.68 & 211 & $.008^{*}$ \\
\hline
\end{tabular}

Note: The alpha level was adjusted separately for online and in-class teacher comparisons. Significance was established using $\alpha / 5=.01$.

* Signifies statistical significance for $\alpha=.01$ 


\section{F. Time Spent During Algebra I Sessions}

In view of the different roles that the in-class and online teachers were expected to fulfill in the implementation of the Algebra I Online classrooms, it was important to explore how the teachers spent their time in class. The online and in-class teachers were each asked to share information about the amount of time they spent on a variety of activities during a typical Algebra I class. Due to the nature of their day-to-day work and often different roles, the prompts for the online and in-class teachers varied.

Table 8 shows that 5 of the 10 online teachers reported spending more than $50 \%$ of their time communicating with students via email or grading students' assignments and homework. The most variability in the time spent during the typical Algebra I Online classroom was spent communicating with the in-class teacher; 5 of the 10 online teachers said that they spent less than $25 \%$ of their time on this activity.

Fourteen of the 16 in-class teachers reported spending less than $25 \%$ of their time reviewing assignments and homework with their class or getting students started. Only one in-class teacher reported spending more than $50 \%$ of his/her time presenting new math content to whole class. Although 15 of the 16 in-class teachers said that they spent less than $25 \%$ of their time working with small groups of students, 10 of the 16 in-class teachers reported spending time $(>26 \%)$ working with individual students.

Table 8: Teacher Time Spent During Typical Algebra I Session

\begin{tabular}{|c|c|c|c|c|}
\hline $\begin{array}{l}\text { How much time do you devote to each of the } \\
\text { following types of activities for a typical Algebra } 1 \\
\text { session? }\end{array}$ & $\begin{array}{l}\text { Little } \\
(<10 \%)\end{array}$ & $\begin{array}{c}\text { Some } \\
(11-25 \%)\end{array}$ & $\begin{array}{c}\text { A lot } \\
(26-50 \%)\end{array}$ & $\begin{array}{l}\text { Most of the time } \\
\qquad(>50 \%)\end{array}$ \\
\hline \multicolumn{5}{|l|}{ Online Teachers $(\mathrm{N}=10)$} \\
\hline $\begin{array}{l}\text { Communicating with the in-class teacher (via e- } \\
\text { mail, phone, or other) }\end{array}$ & $2(20 \%)$ & $3(30 \%)$ & $4(40 \%)$ & $1(10 \%)$ \\
\hline Communicating with students via e-mail & $0(0 \%)$ & $3(30 \%)$ & $2(20 \%)$ & $5(50 \%)$ \\
\hline Grading students' assignments and homework & $0(0 \%)$ & $1(10 \%)$ & $4(40 \%)$ & $5(50 \%)$ \\
\hline \multicolumn{5}{|l|}{ In-class Teachers $(\mathrm{N}=16)$} \\
\hline Presenting new math content to whole class & $8(50 \%)$ & $3(19 \%)$ & $4(25 \%)$ & $1(6 \%)$ \\
\hline $\begin{array}{l}\text { Reviewing assignments and homework with their } \\
\text { class }\end{array}$ & $7(44 \%)$ & $7(44 \%)$ & $2(13 \%)$ & $0(0 \%)$ \\
\hline Getting students started & $7(44 \%)$ & $7(44 \%)$ & $2(13 \%)$ & $0(0 \%)$ \\
\hline Working with individual students & $0(0 \%)$ & $6(38 \%)$ & $9(56 \%)$ & $1(6 \%)$ \\
\hline Working with small groups of students & $3(19 \%)$ & $12(75 \%)$ & $1(6 \%)$ & $0(0 \%)$ \\
\hline
\end{tabular}

To further examine how teachers spent their time during a typical Algebra I session, the variable representing the amount of time spent was dichotomized. This allowed us to compare student posttest scores for teachers who spent relatively small amounts of time $(<25 \%$ of their time $)$ to the student posttest scores for teachers who reported spending larger amounts of time ( $>25 \%$ of their time) on these activities. Again, independent means t-tests were used to examine the significance of the differences 
between the means and an adjusted alpha-level used to adjust for multiple comparisons within a single data set.

The data in Table 9 show that students' whose online teachers reported spending more time grading assignments and homework (15.85) had statistically significantly higher posttest scores than students whose online teachers reported spending less time on this activity (11.11). Similarly, students whose inclass teachers reported spending more time working with small groups of students (18.27) had statistically significantly higher posttest scores than students whose teachers spent less time working with small groups of students (14.71). Students whose in-class teachers spent more time getting students started during the typical Algebra I session (10.00) had statistically significantly lower posttest scores than students whose in-class teachers spent less time on this (15.75). These findings are not surprising since these activities indicate a greater engagement between the teacher and the student around Algebra content.

Table 9: Student Posttest Means and Teacher Time Spent During Typical Algebra I Session

\begin{tabular}{|c|c|c|c|c|c|}
\hline $\begin{array}{l}\text { How much time do you devote to each of the } \\
\text { following types of activities for a typical Algebra } \\
1 \text { session? }\end{array}$ & $\begin{array}{l}\text { Little or Some of } \\
\text { the Time } \\
(<10 \% \text { to } 25 \%)\end{array}$ & $\begin{array}{l}\text { A lot or Most of } \\
\text { the time } \\
(26 \% \text { to }>50 \%)\end{array}$ & $\mathrm{t}$ & df & $\mathrm{p}$-value \\
\hline & \multicolumn{2}{|c|}{ Students' Posttest Mean (s.e.) } & & & \\
\hline \multicolumn{6}{|l|}{ Online Teachers } \\
\hline $\begin{array}{l}\text { Communicating with the in-class teacher (via e- } \\
\text { mail, phone, or other) }\end{array}$ & $14.54(.88)$ & $15.97(.46)$ & -1.60 & 110 & .113 \\
\hline Communicating with students via e-mail & $15.64(.92)$ & $15.41(.48)$ & 0.25 & 110 & .806 \\
\hline Grading students' assignments and homework & $11.11(.92)$ & $15.85(.44)$ & -3.11 & 110 & $.002^{*}$ \\
\hline \multicolumn{6}{|l|}{ In-class Teachers } \\
\hline Presenting new math content to whole class & $15.52(.38)$ & $14.31(.54)$ & 1.86 & 211 & .064 \\
\hline $\begin{array}{l}\text { Reviewing assignments and homework with } \\
\text { their class }\end{array}$ & $15.17(.33)$ & $14.68(.87)$ & 0.61 & 211 & .543 \\
\hline Getting students started & $15.75(.32)$ & $10.00(.68)$ & 6.39 & 211 & $.000 * \star$ \\
\hline Working with individual students & $14.89(.49)$ & $15.17(.41)$ & -0.42 & 211 & .674 \\
\hline Working with small groups of students & $14.71(.33)$ & $18.27(.85)$ & -3.53 & 211 & $.001^{\star *}$ \\
\hline
\end{tabular}

Note: The alpha level was adjusted separately for online and in-class teacher comparisons. Significance was established using $\alpha / 3=.017$ for the online teachers and $\alpha / 5=.01$ for the in-class teachers.

* Signifies statistical significance for $\alpha=.017$

$* *$ Signifies statistical significance for $\alpha=.01$

In-class teachers were also asked to identify the amount of time during a typical Algebra I Online class that their students spend on a variety of activities. Table 10 shows that more than half the in-class teachers said that their students spent less than $25 \%$ of their time in class listening to presentations of new materials, working in small groups, reading/doing problems from the text, or interestingly, discussing 
mathematics. Recall that prior analysis of the student survey data that compared students in the Algebra I Online classrooms to match traditional, face-to-face classrooms [31] found that students in the Algebra I Online classrooms reported spending more time interacting with their peers to talk about the content of the course and working together on course activities than students in the comparison classrooms. According to more than half the in-class teachers, their students spent a lot or most of the time working individually or working online.

Table 10: In-class Teacher Reports on How Students Spent Time During Typical Algebra I Session

\begin{tabular}{l|cccc}
\hline $\begin{array}{l}\text { How much time did your students spend engaging } \\
\text { in each of the following types of activities? }\end{array}$ & $\begin{array}{c}\text { Little } \\
(<10 \%)\end{array}$ & $\begin{array}{c}\text { Some } \\
(11-25 \%)\end{array}$ & $\begin{array}{c}\text { A lot } \\
(26-50 \%)\end{array}$ & $\begin{array}{c}\text { Most of the time } \\
(>50 \%)\end{array}$ \\
\hline Listening to presentations of new content & $9(56 \%)$ & $2(13 \%)$ & $4(25 \%)$ & $1(6 \%)$ \\
Working individually & $1(6 \%)$ & $4(25 \%)$ & $3(19 \%)$ & $8(50 \%)$ \\
Working in small groups & $1(6 \%)$ & $9(56 \%)$ & $6(38 \%)$ & $0(0 \%)$ \\
Reading/doing problems from the text & $4(25 \%)$ & $7(44 \%)$ & $5(31 \%)$ & $0(0 \%)$ \\
Working online & $2(13 \%)$ & $0(0 \%)$ & $9(56 \%)$ & $5(31 \%)$ \\
Discussing mathematics & $2(13 \%)$ & $8(50 \%)$ & $5(31 \%)$ & $1(6 \%)$ \\
\hline
\end{tabular}

Similar to the previous analyses, the variable representing the amount of time spent was dichotomized. This allowed us to compare student posttest scores for teachers who reported that their students spent relatively small amounts of time ( $<25 \%$ of their time) to the scores for teachers who reported that their students spent larger amounts of time ( $>25 \%$ of their time) on these activities. Again, independent means $\mathrm{t}$-tests were used to examine the significance of the differences between the means and an adjusted alphalevel used to adjust for multiple comparisons within a single data set.

The results in Table 11 show only small differences between the mean posttest scores for students whose teachers report varying amounts of time spent. Using the conservative significance level $(\alpha / 7=.007)$, the results indicate that none of the differences between the mean posttest scores were statistically significant.

Table 11: Student Posttest Means and In-class Teacher Reports on How Students Spent Time During Typical Algebra I Session

\begin{tabular}{|c|c|c|c|c|c|}
\hline $\begin{array}{l}\text { How much time did your students spend } \\
\text { engaging in each of the following types of } \\
\text { activities? }\end{array}$ & $\begin{array}{l}\text { Little or Some of } \\
\text { the Time } \\
(<10 \% \text { to } 25 \%)\end{array}$ & $\begin{array}{l}\text { A lot or Most of } \\
\text { the time } \\
(26 \% \text { to }>50 \%)\end{array}$ & $\mathrm{t}$ & df & p-value \\
\hline & \multicolumn{2}{|c|}{$\begin{array}{l}\text { Students' Posttest Mean for } \\
\text { In-class Teachers (s.e.) }\end{array}$} & & & \\
\hline Listening to presentations of new content & $15.17(.38)$ & $14.87(.58)$ & 0.45 & 211 & .654 \\
\hline Working individually & $14.14(.61)$ & $15.50(.36)$ & -2.00 & 211 & .046 \\
\hline Working in small groups & $15.16(.38)$ & $14.92(.57)$ & 0.36 & 211 & .717 \\
\hline
\end{tabular}


The Louisiana Algebra I Online Initiative as a Model for Teacher Professional Development: Examining Teacher Experiences

\begin{tabular}{l|ccccc}
\hline Reading/doing problems from the text & $15.21(.38)$ & $14.85(.56)$ & 0.55 & 211 & .581 \\
Working online & $13.07(.78)$ & $15.38(.34)$ & -2.50 & 211 & .013 \\
Discussing mathematics & $15.64(.37)$ & $14.05(.56)$ & 2.44 & 211 & .015 \\
\hline
\end{tabular}

\section{G. Narrative Responses}

In addition to the forced-choice survey questions, the in-class and online teachers were invited to respond to several open-ended questions about their experiences in the Louisiana Algebra I Online program. The questions asked teachers to reflect on their mentor/mentee partnership, the positive and negative aspects of the initiative for students, as well the positive and negative aspects of the initiative for them as either in-class or online teachers.

For the in-class teachers, the most rewarding aspect of the mentor/mentee relationship was having the online teacher available as a resource for content-related questions. The in-class teachers also said that the partnership with the online teacher provided them with the opportunity to collaborate on ways to help students understand difficult concepts and also helped them to "use a different approach to teaching some of the concepts." For the online teachers, the benefits of the partnership were around teamwork and the benefit of having two teachers providing help, support, and assistance to the students. A theme that emerged frequently was that the in-class teacher served as the online teachers' "eyes and ears" in the classroom to help monitor the students and provide extra instruction. Given the online teachers' lack of physical presence in the classroom, in-class teachers' fulfillment of this role is particularly salient.

When asked about the positive aspects of the Algebra I Online course for students, the in-class and online teachers overwhelmingly said that exposure to technology and the high quality of the curriculum provided by Algebra I Online were the most positive aspects of the course. One online teacher said that the most positive aspect for students was "having an opportunity to master technology and mathematics concepts at the same time." Some in-class and online teachers viewed the course as a useful opportunity for students to develop their skills to work and learn independently. Having said this, several in-class and online teachers also raised the independent nature of the learning as a challenge for students. Teachers, particularly the in-class teachers, recognized that the delayed feedback and being unable to "ask questions and get an answer during class time" was difficult for students. Half of the online teachers felt that students' lack of technical skills was the most challenging aspect for their students.

The in-class teachers reported that an increase in their algebra content knowledge and an increase in their technology skills was were the most positive aspects of their own participation in the program. For the online teachers, the benefit of the program was in using the technology to support their teaching activities. One online teacher said that she "enjoyed the technology and the fact that it provides me with a way to do something I love" while another said "I enjoy using technology and I love teaching, so this is a great combination for me." Interestingly, the asynchronous nature of the feedback that was mentioned by the in-class teachers as a challenge for the students was mentioned as a benefit for the online teachers themselves. For example, a teacher said that "having an opportunity to really think about my responses to student questions and provide them with the best answer possible" was very beneficial. When asked what was most challenging about their role, in-class teachers reported "not having sufficient time" to complete the lessons and some felt that they did not understand their students' progress because they weren't responsible for student assessments or grading. Not surprisingly, the online teachers reported that the lack 
of face-to-face contact with their students was the most challenging aspect for them as professionals.

The in-class and online teachers' responses to these open-ended prompts provided a useful insight into their experiences. While themes similar to those raised in the forced-choice questions emerged from teachers' narratives, some interesting differences arose between the in-class and online teachers' experiences and the perceived experiences for their students. In addition to the changes to teaching and learning that we have to expect in the online environment (e.g., changes in class structure [17], the level and types of peer-to-peer and student-teacher interactions that take place [15, 18], and the lack of "social presence" during the learning process $[19,20,21])$, the very nature of Algebra I Online program places a new emphasis on collaboration and shared classroom "space."

\section{CONCLUSIONS AND DISCUSSION}

Facing demands to meet the current mandates of the NCLB Act for improving student achievement and for providing students with highly qualified teachers in every classroom, several states have turned to online learning programs for increasing student achievement and for providing effective teacher professional development in core academic areas. The Louisiana Algebra I Online initiative for eighth and ninth grade students in Louisiana is one such model. The program was designed and implemented to bring highly qualified mathematics teachers to students in places where they would not be otherwise available, to provide students with the structure of a regular class period, and to provide a unique professional development model for local teachers.

Previous research examining student data from the implementation of the Algebra I Online model found that after controlling for initial pre-intervention measures of mathematics ability, students who participated in the initiative scored as well on the posttest as students in traditional face-to-face Algebra I courses [31]. While the students in the online Algebra I course scored as well as students in the matched comparison classrooms, there were differences in their learning experiences. Though the student responded positively to the online environment, they reported lower levels of confidence in their algebra skills than students in the traditional, face-to-face algebra courses. This finding may be the result of students being unable to gauge their progress in the course because of delayed feedback and dispersed authority in the online environment. Other differences were found in the level and type of student interactions between the online and traditional instructional models. What these findings suggest is that the characteristics of the learning environment appear to alter when content is delivered online, either fully or as part of a hybrid model similar to the Algebra I Online approach.

As an extension of the investigation of student measures and their relationship between student learning outcomes, this paper examined the experiences of teachers working within the Algebra I Online model frameworks. In addition, this research explored the important question of whether teacher practices were related to student learning outcomes. Just as we saw student experiences differ, the findings presented in this paper show that teachers participated in useful professional development opportunities, experienced interesting benefits and faced new challenges through their participation in the Louisiana Algebra I Online initiative.

According to recent research and writings, some key components of effective professional development include individualizing development approaches to allow teachers to master new strategies for meeting the day-to-day challenges in their classrooms [32, 33], providing for "collaborative analysis and interpretation" of classroom experiences [34], and embedding professional development opportunities for teachers in their everyday professional lives [33]. Through its formal professional development 
workshops and ongoing model of mentor/mentee partnership and collaboration throughout the school year, the Louisiana Algebra I Online model espouses these key components.

The in-class and online teachers responded very positively about their experiences in the formal professional development components of the model and the in-class teachers were very positive about the year-long partnership with their mentor. Local teachers reported that the most rewarding aspect of the professional development model was having the online teacher available as a resource for content-related questions and being able to collaborate on ways to help students understand difficult concepts.

An important component for the success of educational technology initiatives, particularly one that requires substantial investments in terms of time and resources, is the level of school and district support [36]. While successful implementation of an initiative might not always lead to improved outcomes, without local support for program implementation the impact of an initiative might be jeopardized. Given the large investments in resources and support for the Algebra I Online program, it was very encouraging to see that teachers felt very positive about the resources and support available to them during the course.

It was interesting to see the ways in which the in-class and online teachers' experiences differed. For example, the two groups of teachers rated their students' interest in the online course quite differently. More in-class teachers said that the students' interest in the course was about the same, somewhat or much lower than for a traditional course than the online teachers. By way of another example, more inclass teachers reported facing challenges in the program than the online teachers. Also, the types of challenges faced differed across the two groups of teachers; the in-class teachers were more likely to report their lack of teaching experience and lack of familiarity with technology as a challenge than the online teachers. These findings are not entirely surprising since the online teachers were master teachers selected because of their excellent teaching record and their experience with technology.

Another important finding was that while each of the in-class teachers said that the program increased their algebra-related content knowledge, about one-third of the teacher perceived no benefit for their classroom teaching skills. While we can only speculate the reasons for this pattern, this finding suggests that the type of activities which the in-class teachers were required to engage in (creating an atmosphere conducive to learning, assisting students with technology, supervising and instructing the Algebra I students, working with students when problems arose, keeping the online teacher informed about individual student issues and class activities, monitoring student grades, and providing feedback on activity days) were quite different to the typical role fulfilled by a classroom teacher in the traditional face-to-face environment and so did not necessarily provide an adequate professional development model for improving general classroom teaching skills.

Since models for professional development are generally directed towards improving student outcomes and in particular, student learning outcomes, it was noteworthy that achievement was generally lower for students in classrooms where the in-class teachers reported challenges such as a lack of teaching experience or experience with technology, or reported having difficulty substantiating student participation. There were also differences in students' posttest scores according to whether teachers seldom or frequently communicated, and the differences varied according to the purpose of the communication. For example, students' posttest mean scores were higher for teachers who communicated frequently with the in-class teacher for planning lessons and for discussing individual student's work. The data also showed that students whose in-class teachers reported spending more time working with small groups of students had higher posttest scores than students whose teachers spent less time working with small groups of students. 
Recognizing the limitations of the small number of teachers included in this study and the limitations of self-reported observational data, in particular for making causal inferences, the research presented here provides us with important insights into the particular characteristics of the online teaching environment and how such an environment might be used to support the professional development of teachers in regions where teacher recruitment and retention are programs. Given the vast expenditures for online programs in $\mathrm{K}-12$ in recent years, we are facing a critical need for evidence-based research to inform the proliferation of online distance learning initiatives. With more than half a million elementary, middle and high school students and their teachers impacted by some form of online learning initiative during the 2004-2005 school year, it is vital that the educational community and in particular state and local decision-makers have access to high-quality research they can use to inform their ongoing investments in online learning initiatives.

Since its pilot year in 2002-2003, 57 teachers have taken part in the Algebra I Online initiative as in-class teachers. From the pool of previously uncertified local teachers, 5 earned certification in secondary mathematics, 3 earned middle school mathematics certification, and 1 earned National Board Certification in Mathematics/Early Adolescence (grades 11-15). Of the 16 in-class teachers that participated during the 2004-2005 implementation, 2 earned certification in secondary mathematics. Although there are many types of online and distance learning models available for schools and districts, the findings from this research suggest that the Louisiana Algebra I Online model may be a viable approach for providing local teachers with effective professional development opportunities that are embedded within their day-to-day teaching activities and individualized to allow them to master new strategies for meeting the challenges in their classrooms.

\section{ABOUT THE AUTHOR}

Laura O'Dwyer is an Assistant Professor at the Lynch School of Education at Boston College where she teaches statistics, quantitative research methods and experimental design. Her research focuses on examining the effects of organizational characteristics on individual outcomes, international comparative studies, and educational technology as a teaching and learning tool.

Rebecca Carey is a Project Director in the Northeast and Islands Regional Laboratory and the Center for Online Professional Education. Her research focuses on applied research in educational technology, specifically online education for students and adults.

Glenn Kleiman is Vice President of Education Development Center, Inc., Director of the EDC Center for Online Professional Education, and Co-Director of the Regional Education Laboratory for the Northeast and Islands Region. His work focuses on applied research to inform policy and program decisions about educational innovations.

\section{REFERENCES}

1. Smith, R., T. Clark and R. L. Blomeyer. A Synthesis of New Research on K-12 Online Learning. 2005. Retrieved December 12, 2006 from http://www.ncrel.org/tech/synthesis/.

2. Perreault, H., L. Waldman and M. A. J. Zhao. Overcoming barriers to successful delivery of distance learning courses. Journal of Education for Business 77(6): 313-318, 2002.

3. No Child Left Behind Act of 2001. Pub. L. 107-110, §1606, 115 Stat. 1425, 2002. 
4. Setzer, J. C. and L. Lewis. Distance Education Courses for Public Elementary and Secondary School Students: 2002-03 (NCES 2005-010). U.S. Department of Education. Washington, DC: National Center for Education Statistics, 2005.

5. National Education Association. Status of Public Education in Rural Areas and Small Towns: A Comparative Analysis. September 1998.

6. Beeson, E. and M. Strange. Why Rural Matters 2003: The Continuing Need for Every State to Take Action on Rural Education. Washington, DC: Poverty \& Race Research Action Council, 2003. Retrieved September 13, 2005 from http://www.ruraledu.org/streport/streport.html.

7. Loomis, S. C. and M. L. Bourque (Eds.). National Assessment of Educational Progress Achievement Levels, 1992-1998 for Mathematics. Washington, D.C.: National Assessment Governing Board, 2001.

8. Kilpatrick, J., J. Swafford and B. Findell (Eds.). Adding it Up: Helping Children Learn Mathematics. Mathematics Learning Study Committee, Center for Education, Division of Behavioral and Social Sciences and Education, Washington, D.C.: National Academy Press, 2001.

9. National Center for Education Statistics. Distance Education Course for Public Education and Secondary School Students: 2002. Washington, D.C.: Institute of Education Sciences, National Center for Education Statistics, 2002. Retrieved September 13, 2005 from http://nces.ed.gov/surveys/frss/publications/2005010/.

10. Southwest Educational Development Laboratory (SEDL). Evaluation of the Algebra I Online Pilot Project: 2002-2003, 2004.

11. Cavanaugh, $\mathbf{C}$. The effectiveness of interactive distance education technologies in $\mathrm{K}-12$ learning: $\mathrm{A}$ meta-analysis. International Journal of Educational Telecommunications 17(1): 73-88, 2001. Retrieved September 13, 2005 from http://www.unf.edu/ ccavanau/CavanaughIJET01.pdf.

12. Ungerleider, C. S. and T. C. Burns. Information and communication technologies in elementary and secondary education: A state of the art review. Paper presented at the Pan-Canadian Education Research Agenda Symposium, Montreal, Quebec, 2002. Retrieved September 12, 2005 from http://www.cesc.ca/pceradocs/2002/papers/CUngerleider OEN.pdf.

13. Cavanaugh, C., K. J. Gillan, J. Kromrey, M. Hess and R. Blomeyer. The Effects of Distance Education on K-12 Student Outcomes: A Meta-Analysis. Naperville, IL: Learning Point Associates, 2004. Retrieved December 12, 2006 from http://www.ncrel.org/tech/distance/k12distance.pdf.

14. Stodel, E. J., T. L. Thompson and C. J. MacDonald. Learners' perspectives on what is missing from online learning: Interpretations through the community of inquiry framework. The International Review of Research in Open and Distance Learning 7(3): 2006. Retrieved on January 16, 2007 from http://www.irrodl.org/index.php/irrodl/article/view/325/743.

15. Bernard, R. M., P. C. Abrami, Y. Lou, E. Borokhovski, A. Wade, L. Wozney, P. A. Wallet, M. Fiset and B. Huang. How does distance education compare to classroom instruction? A metaanalysis of the empirical literature. Review of Educational Research 74(3): 379-439, 2004.

16. Peters, O. Learning with new media in distance education. In M. G. Moore and W. G. Anderson (Eds.), Handbook of Distance Education, 87-112. Mahwah, NJ: Erlbaum, 2003.

17. Paloff, R. M. and K. Pratt. Lessons From the Cyberspace Classroom: The Realities of Online Teaching. San Francisco: Jossey-Bass, 2001.

18. Lally, V. and E. Barrett. Building a learning community online: Towards socio-academic interaction. Research Papers in Education 14(2): 147-163, 1999.

19. Bibeau, S. Social presence, isolation, and connectedness in online teaching and learning. From the literature to real life. Journal of Instruction Delivery Systems 15(3): 35-39, 2001.

20. Aragon, S. R. Creating social presence in online environments. New Directions for Adult and Continuing Education 100: 57-68, 2003.

21. Garrison, D. R. and M. Cleveland-Innes. Facilitating cognitive presence in online learning: Interaction is not enough. American Journal of Distance Education 19(3): 133-148, 2005.

22. Lockyer, L., J. Patterson and B. Harper. ICT in higher education: Evaluating outcomes for health education. Journal of Computer Assisted Learning 17: 275-283, 2001. 
23. Neuhauser, C. Learning style and effectiveness of online and face-to-face instruction. American Journal of Distance Education 16(2): 99-113, 2002.

24. Thirunarayanan, M. O. and A. Peres-Prado. Comparing web-based and classroom based learning: A quantitative study. Journal of Research on Technology in Education 34(2): 131-137, Winter 2001-2002.

25. Allen, M., J. Bourhis, N. Burrell and E. Mabry. Comparing student satisfaction with distance education to traditional classrooms in higher education: A meta-analysis. American Journal of Distance Education 16(2): 83-97, 2002.

26. Sherry, A. C., C. P. Fulford and S. Zhang. Assessing distance learners' satisfaction with instruction: A quantitative and qualitative measure. American Journal of Distance Education 12(3): 4-28, 1998.

27. Navarro, P. and J. Shoemaker. Performance and perceptions of distance learners in cyberspace. American Journal of Distance Education 14(2): 15-35, 2000.

28. Muilenburg, L. and Z. L. Berge. Barriers to distance education: A factor-analytic study. American Journal of Distance Education 15(2): 7-22, 2001.

29. Smith, P. L. and C. L. Dillion. Comparing distance learning and classroom learning: Conceptual considerations. American Journal of Distance Education 13(2): 6-23, 1999.

30. Cooper, L.W. A comparison of online and traditional computer applications classes. Technological Horizons in Education 28(8): 52-58, 2001.

31. O'Dwyer, L. M., R. Carey and G. Kleiman. A study of the effectiveness of the Louisiana Algebra I Online Course. Journal of Research on Technology in Education 39(3): 2007.

32. Sparks, D. and S. Hirsh. A National Plan for Improving Professional Development. National Staff Development Council, 2000. Retrieved April 19, 2006 from http://www.nsdc.org/library/authors/NSDCPlan.cfm.

33. Lock, J. V. A new image: Online communities to facilitate teacher professional development. Journal of Technology and Teacher Education 14(4): 663-678, p.669, 2006.

34. Cochran-Smith, M. and S. L. Lytle. Beyond certainty: Taking an inquiry stance on practice. In A. Lieberman and L. Miller (Eds.), Teachers Caught in the Action: Professional Development that Matters, 45-58. New York, NY: Teachers College Press, 2001.

35. Kleiman, G., R. Carey, E. Halsted and L. M. O'Dwyer. A Study of the Effectiveness of the Louisiana Algebra I Online Project Final Report. Boston, MA: Center for Online Professional Education, Educational Development Center, 2005.

36. O'Dwyer, L.M., M. Russell and D. J. Bebell. Identifying teacher, school and district characteristics associated with elementary teachers' use of technology: A multilevel perspective. Education Policy Analysis Archives 12(48): September 14, 2004. Retrieved September 14, 2004 from http://epaa.asu.edu/epaa/v12n48/. 